DOI: http://dx.doi.org/10.21123/bsj.2020.17.3(Suppl.).1113

\title{
Prevalence and Characterization of Some Colibactin Genes in Clinical Enterobacteriaceae isolates from Iraqi Patients
}

\author{
Mohammed T. Hussein $\quad$ Safaa A. S. Al-Qaysi ${ }^{2^{*}} \quad$ Munther H. Rathi $^{1}$ \\ Qasim I. Hussein ${ }^{3} \quad$ Tarek A.A. Moussa ${ }^{4 *}$
}

\author{
${ }^{1}$ Department of Biology, College of Science, University of Diyala, Diyala, Iraq \\ E-mail: m4845334@ gmail.com, \\ Prof.dr.rathi@sciences.uodiyala.edu.iq \\ *ORCID ID:0000-0003-3632-6398 \\ 2 Department of Biology, College of Science for Women, University of Baghdad, Baghdad, Iraq. \\ *Corresponding authors: *safaaa_bio@csw.uobaghdad.edu.iq, safaa.ahmed.bio@gmail.com \\ *ORCID ID: 0000-0002-5531-9532 \\ ${ }^{3}$ Baghdad Health Department/Rusafa, Ibn Al-Baladi Hospital for Children and Women, Ministry of Health, Baghdad, \\ Iraq \\ E-mail: noor19620@gmail.com \\ ${ }^{4}$ Department of Botany and Microbiology, Faculty of Science, Cairo University, Giza 12613, Egypt \\ E-mail: tarekmoussa@yahoo.com, tarekmoussa@cu.edu.eg \\ *ORCID ID: 0000-0002-5612-4366
}

Received 30/1/2020, Accepted 29/4/2020, Published 8/9/2020

This work is licensed under a Creative Commons Attribution 4.0 International License.

\begin{abstract}
:
The members of the family of Eentrobacteriaceae harbour a gene cluster called polyketide synthase ( $p k s)$ island. This cluster is responsible for the synthesis of the genotoxin colibactin that might have an important role in the induction of double-strand DNA breaks, leading to promote human colorectal cancer (CRC). Eleven out of the eighty eight isolates (12.5\%) were pks+, distributed as 7 (8\%) isolates of E. coli, 2 $(2.25 \%)$ of $K$. pneumoniae and $2(2.25 \%)$ of E. aerogenes. The cytotoxic effects of selected $p k s+$ isolates $(E$. coli and E. aerogenes) on HeLa cells were represented by decreasing cell numbers and enlarged cell nuclei in comparison to the untreated cells. Cytological changes were observed when the infected HeLa cells cultures were stained with $\mathrm{AO} / \mathrm{EBr}$ and visualized under fluorescent microscope. Some changes that happened in the color of the nuclear chromatin were accompanied by DNA condensation and degradation and fragmentation of nuclei. HeLa cells with green unchanged nuclear chromatin were alive while those with orange-dark and bright red nuclei were dead. It was concluded that a proportion of the Entreobacteriaceae isolates from Iraqi patients was pks+, which exerted cytotoxic effects upon using them to kill HeLa cells. In this study the microscopic observation of the cell morphology reveals the cellular response to the genotoxic insult, with reduced numbers, striking giant cells phenotype (megalocytosis) and fragmentation of nuclei due to the cell cycle arrest and cellular senescence.
\end{abstract}

Key words: Colibactin ( $p k s$ Island), Cytotoxicity, Eentrobacteriaceae, Genotoxin, Prevalence

\section{Introduction:}

Colibactins are natural genotoxic small molecules of unknown structure, produced by human normal intestinal microbiota. These molecules are considered as secondary metabolites, and their biosynthesis is encoded by specific gene cluster which was firstly identified and characterized by Oswald with many co-workers during 2006 in an extra-intestinal pathogenic Escherichia coli strain (ExPEC) isolated from neonatal meningitis $(1,2)$.
Epidemiological studies and reports showed that colibactin can also be produced by extra-intestinal pathogenic strains of Enterobacteriaceae members including Klebsiella pneumoniae, Enterobacter aerogenes, Citrobacter koseri and was also found in Pseudovibiro spp. associated with sponges isolated from marine water $(3,4)$. The biosynthesis of this bacterial toxin is achieved by the enzymes Polyketide synthases (PKSs) and non-ribosomal 
peptide synthases (NRPSs). The major biosynthesis of these secondary metabolites is encoded by the $\mathrm{clb}$ $A-S$ genes found in the 54-kb genomic pks island and any mutation in these genes except $c l b S$, results in a decreased in or loss of the genotoxic activity $(5,6)$. The importance of this gene cluster in colibactin synthesis is represented by $\operatorname{clb} A ; \mathrm{a}$ phosphopantetheinyl transeferase-encoded gene (PPTase); and clbP; a D-amino peptidase; which are required for the biosynthesis and maturation of colibactin, respectively (7). The mechanisms of mode of action are poorly identified, and characterization of its structure remains partially elusive, though a previous study of Brotherton and Balskus (8) demonstrated that the assembly pathway of colibactin as a prodrug is mediated with NRPSPKS biosynthesis machinery with an extended side chain on N-acyl-D-asparagine. The precursor (precolibactin) is then translocated into the periplasm by $\mathrm{clb} \mathrm{M}$ transporter, and the tether is removed by $c l b P$. The production of colibactins was associated with pathogenicity and cancer. They are considered as virulence factors, immunomodulators, mutualistic factors, and antimicrobial agents, with reported antiinflammatory and analgesic effects $(9,10)$. This natural genotoxin induces the breakdown of doublestranded DNA, chromosome aberrations, and cell arrest in the G2/M phase in the eukaryotic host cells $(2,11)$. Interestingly, The members of Enterobacteriaceae such as $E$. coli and $K$. pneumoniae harbouring pks were isolated from several clinical cases such as newborn meningitis (12), commensal bacteria found in human and animal intestinal tracts (13), patients with urinary tract infections (14), and haemo culture (septicemia) $(7,15)$. In addition, E. coli harboring $p k s$ are isolated from colorectal cancer (CRC) and they could promote human CRC development (16). It was revealed that the ability of $K$. pneumoniae strain 1084 harbouring $p k s$ cluster to damage DNA in vitro and in vivo is significantly demolished when $c l b A$ was knocked out (12). However, it was reported that $c l b P$ can ease the harmful effect of this toxin in vitro and dramatically decreases the tumor number in vivo (17). This works aimed to investigate the prevalence of some genes responsible for the production of colibactin among the clinically isolated Enterobacteriaceae infected patients in Iraq. Additionally, determined the ability of the harbouring isolates of the $p k s$ genes to induce in vivo cytotoxic effects and genetic damage on the HeLa cell line.

\section{Materials and Methods: Bacterial isolation and Identification}

For the isolation of Enterobacterieaceae, various clinical specimens (stool, urine, blood and wound swabs) were collected from different patients to avoid duplication. All isolates were collected during eight-month period from April 2018 to January 2019, from selected medical centers and hospitals that were (Ibn Al-Baladi Hospital for Children and Women, Educational Laboratories/ Medical City and Central public Health Laboratory), in Baghdad/Iraq. The collected Enterobacteriaceae isolates were further identified and characterized to species level using several approaches like morphology and colony characters. Several types of culture media were used for isolating and purifying which include (Nutrient agar, MacConkey agar, Eosin-Methylene blue agar and Blood agar Simmon citrate agar). All bacterial isolates undergone biochemical tests, physiological characters, API 20E identification system (BioMérieux, La Balme-lesGrottes,France) and were finally confirmed by VITEK-2 system.

\section{DNA Extraction and manipulation}

Total genomic DNA for all Enterobacteriaceae isolates was extracted and prepared using Wizard genomic DNA purification Kit (Promega, USA). Next, 2-4 colonies of each isolate was picked up and incubated in $1 \mathrm{ml}$ LuriaBertani broth (LB) medium and shaked at 180-220 $\mathrm{rpm}$ for $8 \mathrm{~h}$ at $37^{\circ} \mathrm{C}$ according to the manufacturer's recommendation for Gram-negative bacteria, with the exception that DNA was rehydrated with $10 \mathrm{mM}$ Tris- $\mathrm{HCl}$ ( $\mathrm{pH}$ 8.0). The quality and quantity of the extracted DNA were assessed by gel electrophoresis and spectrophotometer (NanoDrop; Thermo Fisher) respectively. The extracted DNA was stored at freezing $\left(-20{ }^{\circ} \mathrm{C}\right)$ and used as a template for subsequent amplifications and detection of $p k s$ genes. The presence of colibactin genes ( $p k s)$ among the collected clinical Entrobacterial isolates was determined using Polymerase Chain Reaction (PCR) technique. The primers used for the amplification of the tested $c l b A, B, N$ and $Q$ genes are listed in Table 1. PCRs were performed using a Hot Start Taq Kit (Qiagen, Limburing, Netherlands) in a $25-\mu 1$ reaction volume containing 1 pmol $\mu \mathrm{l}-1$ of FWD and R primers, $1 \mathrm{X}$ buffer, $1 \mathrm{X}$ Hot Start Taq buffer mix, $1 \mu \mathrm{l}$ DNA, and distilled water (dH2O). PCR conditions were $95^{\circ} \mathrm{C}$ for $15 \mathrm{~min}$ by 35 cycles at $95^{\circ} \mathrm{C}$ for $30 \mathrm{~s}, 53^{\circ} \mathrm{C}$ for $30 \mathrm{~s}$, and $72^{\circ} \mathrm{C}$ for $90 \mathrm{~s}$, followed by 1 cycle of $72{ }^{\circ} \mathrm{C}$ for $10 \mathrm{~min}$. PCR products were detected following the separation by electrophoresis using $1.5 \%$ agarose gel. Bacterial isolates were considered as $p k s+$ after 
qualitative PCR, and, for each clinical sample, $p k s$ prevalence was defined as the proportion of the number of $p k s+$ isolates to that of isolates in that category.

Table 1. Primers used for amplification of the tested $c l b$ genes

\begin{tabular}{|c|c|c|c|}
\hline $\begin{array}{c}c l b \\
\text { genes }\end{array}$ & Sequences & $\begin{array}{l}\text { PCR product size } \\
\text { (bp) }\end{array}$ & Reference \\
\hline$c l b A$ & $\begin{array}{l}c l b A \text { forward 5'-CTAGATTATCCGTGGCGATTC-3' } \\
c l b A \text { reverse 5'-CAGATACACAGATACCATTCA-3' }\end{array}$ & 1002 & \\
\hline$c l b B$ & $\begin{array}{l}c l b B \text { forward 5'-GATTTGGATACTGGCGATAACCG-3' } \\
c^{\prime} l b B \text { reverse 5'-CCATTTCCCGTTTGAGCACAC-3' }\end{array}$ & 550 & [9] \\
\hline$c l b N$ & $\begin{array}{l}c l b N \text { forward 5'-GTTTTGCTCGCCAGATAGTCATTC-3' } \\
c l b N \text { reverse 5'-CAGTTCGGGTATGTGTGGAAGG-3' }\end{array}$ & 700 & \\
\hline$c l b Q$ & $\begin{array}{l}c l b Q \text { forward 5'-CTTGTATAGTTACACAACTATTTC-3' } \\
c l b Q \text { reverse 5'-TTATCCTGTTAGCTTTCGTTC-3's }\end{array}$ & 821 & \\
\hline
\end{tabular}

\section{Antimicrobial susceptibility test}

All bacterial isolates pks+ were assayed by Kirby-Bauer disk diffusion method for antimicrobial susceptibility to the following commercially available antibiotic disk (14 antibiotics) obtained from (Bioanlyse-Turkey), Amikacin (AK $15 \mu \mathrm{g}$ ), Cefotaxime (CTX $30 \mu \mathrm{g}$ ), Gentamicin (GN $10 \mu \mathrm{g}$ ), Ceftriaxone (CRO $30 \mu \mathrm{g}$ ), Imipenem (IMP $10 \mu \mathrm{g}$ ), Meropenem (MEM $10 \mu \mathrm{g}$ ), Ciprofloaxacin (CIP 5 $\mu \mathrm{g}$ ), Piperacillin (PRL $100 \mu \mathrm{g}$ ), Ceftazidime (CAZ $30 \mu \mathrm{g}$ ), Norfloxacin (NOR $30 \mu \mathrm{g}$ ), Chloramphenicol (C $30 \mu \mathrm{g}$ ), Nitrofurantion (NI $30 \mu \mathrm{g}$ ), Cefepime (CPM $30 \mu \mathrm{g}$ ) and Tobramycin (TOB $10 \mu \mathrm{g}$ ). The susceptibility test was done using Mueller Hinton agar (MHA) according to Clinical laboratory Standard Institute (CLSI) guidelines (18). Interpretive criteria applied for classification of the clinical isolates were categorized as Susceptible (S), Intermediate (I) and (R) for Resistant group.

\section{Cytotoxic activity of Bacterial isolates encoding colibactin $\left(p k s^{+}\right)$against HeLa cell line (ex vivo) Cell cultures and Maintenance}

HeLa cells were obtained from the Iraqi Biotech Cell Bank Unit, Baghdad, Iraq. These cells were maintained in the culture medium (RPMI-1640) supplemented with $10 \%$ fetal bovine serum, 100 units $/ \mathrm{mL}$ penicillin, and $100 \mu \mathrm{g} / \mathrm{mL}$ streptomycin. The cells were passaged using Trypsin-EDTA and reseeded at $80 \%$ confluence twice a week and incubated at $37{ }^{\circ} \mathrm{C}, 5 \% \mathrm{CO}_{2}$ and atmospheric $\mathrm{O}_{2}(19)$.

\section{Genotoxicity Assay}

Genotoxic effect of $p k s+$ bacterial isolates was accomplished according to Bossuet-Greifet al., [20] with some modifications. Bacterial cultures of $E$. coli and E. aerogenes pks+ and pks-negative ( $p k s-)$ were activated on LB agar plates, and grown overnight (16-24 h) at $37{ }^{\circ} \mathrm{C}$ with shaking $240 \mathrm{rpm}$. Then bacterial cultures were inoculated into $9.5 \mathrm{ml}$ pre-warmed $\left(37^{\circ} \mathrm{C}\right)$ Dulbecco's modified Eagle medium (DMEM) with $25 \mathrm{mM}$ HEPES in a tube with $0.5 \mathrm{ml}$ of LB medium containing bacterial overnight culture. The culture was grown till OD600 $=0.4$ to 0.5 . The cell viability assay was done using 24 well plates. Cell lines were seeded at $1 \times 105$ cells/well. After $24 \mathrm{hr}$ or until a confluent monolayer was achieved, the cells were infected with pks+ bacterial isolates of $E$. coli and $E$. aerogenes at a multiplicity of infection (MOI) [The number of bacteria per cell at the onset of infection] of 50 for 6 and 24hr (20). The cells were washed three times with 1X PBS. Then, they were incubated with RPMI medium containing $10 \%$ FCS and $100 \mu \mathrm{g} / \mathrm{ml}$ gentamycin. Following $48 \mathrm{hr}$ incubation, they were washed with 1X PBS then stained with crystal violet for 15 minutes. The absorbency and dye binding were determined on a microplate reader by measuring the optical density (OD) at $600 \mathrm{~nm}$. The cells infected with pksbacterial isolates were used as a positive control, and uninfected cells were used as a negative control. The assay was performed in triplicate. The control and treated HeLa cells were observed under an inverted microscope. The Hela cells used as a positive and negative controls were confluent with a normal cells in the number and morphology.

-The inhibition rate of cell growth (the percentage of cytotoxicity) was calculated according to the following equation (19): -

$$
\text { Cytotoxicity }=\mathrm{A}-\mathrm{B} / \mathrm{A} * 100
$$

Where $\mathrm{A}$ and $\mathrm{B}$ are the optical densities of the control and the tested groups, respectively.

\section{Acridine orange/Ethidium bromide staining} assay

To examine the capacity of Colibactin produced by $p k s+$ bacterial isolates to induce damage and breaking of ds DNA of HeLa cells, the acridine orange/ethidium promide $(\mathrm{AO} / \mathrm{EBr})$ doublestaining assay was used. Briefly, HeLa cells were 
grown and placed in 96-well plates followed by infection with $p k s+$ bacterial isolates at MOI 50 for 6 and $24 \mathrm{hr}$. After incubation time, the cells were washed with IX PBS then stained with $\mathrm{AO} / \mathrm{EBr}(10$ $\mu \mathrm{g} \mathrm{mL}^{-1}$ ) and measured within 5 minutes by a BX51 UV fluorescent microscope. This experiment was carried out in triplicate [20].

\section{Statistical analysis}

The obtained data were statistically analyzed using an unpaired t-test with GraphPad Prism 6. Significant differences between means were analyzed at $(p \leq 0.05)$ and expressed as $(M e a n \pm S D)$ for triplicate measurements (21).

\section{Results: \\ Occurrence of Enterobacteriaceae in different clinical specimens}

A total of 88 bacterial isolates of Enterobacteriaceae were collected from 285 clinical samples of hospitalized patients having clinicallyevident infection (patients with urinary tract infection, diarrhea, and infection of different wounds and blood with bacteraemia and septicemia) in various hospital wards. The results showed that the prevalence of $E$. coli was $58 \%(\mathrm{n}=51)$ among the total Enterobaterial isolates, the other bacterial isolates include $K$. pneumoniae $31.8 \%(\mathrm{n}=28)$, and $E$. aurogenes $10.2 \%(\mathrm{no}=9)$, as indicated in Table 2 , the highest percentage of bacterial isolates was obtained from stool and urine samples (49 and 26\%) respectively, Followed by $6 \%$ obtained from wound swab and $7 \%$ from blood samples.

Table 2. Different bacterial isolates obtained from different clinical specimens

\begin{tabular}{|c|c|c|c|c|c|c|}
\hline \multirow{2}{*}{$\begin{array}{l}\text { Types of bacterial } \\
\text { isolates }\end{array}$} & \multicolumn{4}{|c|}{ Types of clinical specimen } & \multirow{2}{*}{$\begin{array}{l}\text { Total of bacterial } \\
\text { isolates No. }\end{array}$} & \multirow[t]{2}{*}{$\%$} \\
\hline & Stool & Urine & Blood & $\begin{array}{l}\text { Wound } \\
\text { swab }\end{array}$ & & \\
\hline E. coli & 38 & 9 & 1 & 3 & 51 & 58 \\
\hline K. pneumonia & 4 & 15 & 6 & 3 & 28 & 31.8 \\
\hline E. aurogenes & 7 & 2 & 0 & 0 & 9 & 10.2 \\
\hline Total & 49 & 26 & 7 & 6 & 88 & 88 \\
\hline
\end{tabular}

Detection of pks encoding genes among the Enterobacterial isolates

Existence of $c l b A, B, N$ and $Q$ genes in the isolated bacteria was determined. The gene of interest was PCR-amplified using specific primer pairs, and the resulted product for each gene was electrophoresed on $1.5 \%$ agarose gel. The DNA gel revealed that $c l b A$ was around $1002 \mathrm{bp}, c l b B 550 \mathrm{bp}$, $c l b N 700 \mathrm{bp}$ and $c l b Q 821 \mathrm{bp}$ in length (Fig. 1).

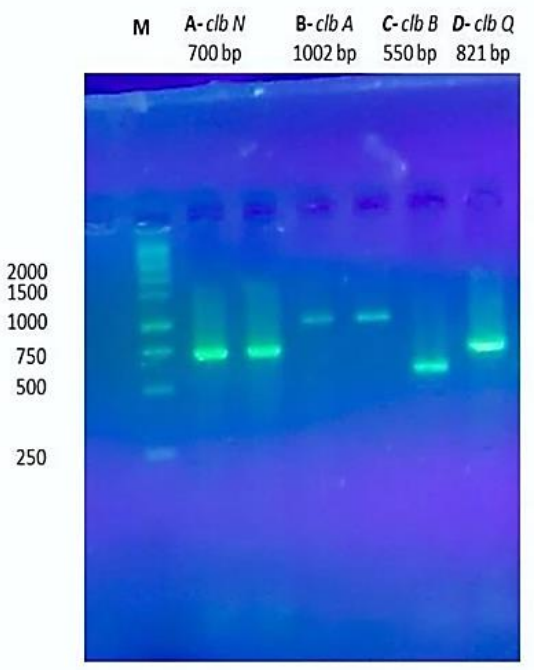

Figure 1, 5\% agarose DNA gel of $c l b$ genes in Enterobacteria, and visualized by UV light. A:
clbN(700bp); B: clbA(1002bp); C:clbB(550bp); and D: $c l b Q(821 \mathrm{bp})$ of $E$. coli isolates $p k s+$. In this case, Lane M: DNA ladder $10 \mathrm{~Kb}$ Molecular Marker (Bioline).

The prevalence of pks genes among Enterobacteriaceae species

Based on the results of PCR analyses, it was noticed that a total of $11(12.5 \%)$ out of 88 tested isolates carried all the screened genes for $p k s+$ island (colibactin-positive) (clb $A, B, N$ and $Q$ ). The distribution of pks+ among the collected clinical isolates showed that 7 isolates belonged to E. coli, 2 isolates to $K$. pneumoniae and 2 to E. aurogenes (Table 3).

Table 3. Numbers of pks+ and pksEnterobacterial isolates according to source of isolation.

\begin{tabular}{|c|c|c|c|}
\hline \multirow[t]{2}{*}{$\begin{array}{l}\text { Bacteria } \\
\text { isolates }\end{array}$} & $\begin{array}{l}\text { No. of } \\
\text { isolates }\end{array}$ & bacterial & \multirow{2}{*}{$\begin{array}{l}P k s+ \\
\text { prevalence } \\
\%\end{array}$} \\
\hline & pks+ & $p k s-$ & \\
\hline E. $\operatorname{coli}(\mathrm{no}=51)$ & 7 & 44 & 8 \\
\hline $\begin{array}{l}\text { K. Pneumoniae } \\
(\mathrm{no}=28)\end{array}$ & 2 & 26 & 2.25 \\
\hline $\begin{array}{l}\text { E. aurogenes } \\
(\mathrm{no}=9)\end{array}$ & 2 & 7 & 2.25 \\
\hline Total (88) & 11 & 77 & 12.5 \\
\hline
\end{tabular}


Table 4 illustrates the numbers of pks+ and $p k s-$ bacterial isolates according to the age of the patients. The highest percentage of $p k s+$ isolates was found in the age between 16 to 50 years. The results also showed that the young people and children (age below 15 years) can be infected with bacteria harbouring $c l b$ genes ( 3 isolates were $p k s+$ ), while 2 isolates were isolated from patients aged $\geqq 51$ years.

Table 4. Numbers of pks+ and pks- bacterial isolates according the age of the patients

\begin{tabular}{|c|c|c|c|}
\hline \multirow{2}{*}{ Age } & \multicolumn{2}{|c|}{ No. of Bacterial isolates } & \multirow{2}{*}{$\begin{array}{c}p k s \\
\text { prevalence } \\
\%\end{array}$} \\
\hline & $p k s+$ & $p k s-$ & \\
\hline $\begin{array}{c}<=15 \\
(\mathrm{no}=32)\end{array}$ & 3 & 25 & 3.4 \\
\hline $\begin{array}{c}16-50 \\
(\mathrm{no}=39)\end{array}$ & 6 & 29 & 6.85 \\
\hline $\begin{array}{c}>=51 \\
(\mathrm{no}=29)\end{array}$ & 2 & 23 & 2.25 \\
\hline Total & 11 & 77 & $12.5 \%$ \\
\hline
\end{tabular}

\section{Antibiotic sensitivity profile of $p k s+$ isolates}

All of the pks+ bacterial isolates were examined for susceptibility against 14 antibiotics as shown in Table 5. In total, the highest sensitive level was recorded for imipenem (100\%) in all these isolates. Among the $7 \mathrm{pks}+$ of $E$. coli isolates, 6 isolates were susceptible to nitrofurantion (94\%) and norofloxacin $(92 \%)$. There was also a remarkable level of resistance to ceftriaxone, cefotaxime, piperacilline and tobramycin. Lower resistance level was observed against norofloxacin, ceftaxidime and nitrofurantion. Interestingly, E. coli showed the highest resistance level to norofloaxacin (96\%) and nitrofurantion (90\%), whereas, in K. pneumoniae the highest resistance was observed against norofloxacin (96.5\%) and neftazidime (93\%), and thus it was also observed that $E$. aerogenes carrying the pks colibactin gene cluster are highly associated with low antimicrobial resistance.

Table 5. The antibiotic sensitivity patterns of all pks+ isolates

\begin{tabular}{|c|c|c|c|c|c|c|}
\hline \multirow[t]{2}{*}{ Antibiotics } & \multicolumn{2}{|c|}{$\begin{array}{c}\text { E.coli } \\
(\mathbf{n}=7)\end{array}$} & \multicolumn{2}{|c|}{$\begin{array}{r}\text { K.pneumonia } \\
(\mathrm{n}=2)\end{array}$} & \multicolumn{2}{|c|}{$\begin{array}{r}\text { E.aerogenes } \\
(n=2)\end{array}$} \\
\hline & $\begin{array}{l}\text { Sensitive } \\
(\%)\end{array}$ & $\begin{array}{l}\text { Resistant } \\
(\%)\end{array}$ & $\begin{array}{l}\text { Sensitive } \\
(\%)\end{array}$ & $\begin{array}{c}\text { Resistant } \\
(\%)\end{array}$ & $\begin{array}{c}\text { Sensitive } \\
(\%)\end{array}$ & $\begin{array}{c}\text { Resistant } \\
(\%)\end{array}$ \\
\hline Amikacin & $4(57)$ & $3(43)$ & $1(50)$ & $1(50)$ & $1(50)$ & $1(50)$ \\
\hline Cefotaxime & $3(43)$ & $4(57)$ & $2(100)$ & $0(0.0)$ & $1(50)$ & $1(50)$ \\
\hline Gentamicin & $1(14)$ & $6(86)$ & $0(0.0)$ & $2(100)$ & $1(50)$ & $1(50)$ \\
\hline Ceftriaxone & $3(43)$ & $4(57)$ & $1(50)$ & $1(50)$ & $1(50)$ & $1(50)$ \\
\hline Imipenem & $7(100)$ & $0(0.0)$ & $2(100)$ & $0(0.0)$ & $2(100)$ & $0(0.0)$ \\
\hline Meropenem & $1(14)$ & $6(86)$ & $2(100)$ & $0(0.0)$ & $2(100)$ & $0(0.0)$ \\
\hline Ciprofloaxacin & $2(28.5)$ & $5(71.5)$ & $0(0.0)$ & $2(100)$ & $0(0.0)$ & $2(100)$ \\
\hline Piperacillin & $3(43)$ & $4(57)$ & $1(50)$ & $1(50)$ & $1(50)$ & $1(50)$ \\
\hline Ceftazidime & $2(28.5)$ & $5(71.5)$ & $1(50)$ & $1(50)$ & $1(50)$ & $1(50)$ \\
\hline Norfloxacin & $4(57)$ & $3(43)$ & $1(50)$ & $1(50)$ & $1(50)$ & $1(50)$ \\
\hline Chloramphenicol & $2(28.5)$ & $5(71.5)$ & $0(0.0)$ & $2(100)$ & $1(50)$ & $1(50)$ \\
\hline Nitrofurantion & $3(43)$ & $4(57)$ & $2(100)$ & $0(0.0)$ & $1(50)$ & $1(50)$ \\
\hline Cefepime & $4(57)$ & $3(43)$ & $2(100)$ & $0(0.0)$ & $1(50)$ & $1(50)$ \\
\hline Tobramycin & $2(28.5)$ & $5(71.5)$ & $1(50)$ & $1(50)$ & $2(100)$ & $0(0.0)$ \\
\hline
\end{tabular}

\section{Cytotoxicity of pks+ Enterobactereacae towards Hela cells}

In order to determine the functionality of $p k s$ cluster in E. coli and E. aerogenes in killing HeLa cells, these cells were either exposed to negative $p k s$ isolates and/or positive pks isolates for two time intervals (6 and $24 \mathrm{hr}$ ) under optimal conditions at MOI 50. The results in Fig. 2 show the cytotoxic effect of all isolates on the normal HeLa cell cultures. Notably, only $10-15 \%$ of normal cells were killed after incubation with $p k s-$ E.coli strain under different times intervals, whereas the percentage of the same cells was increased remarkably (50\%) when they were exposed to $p k s+E$. coli strains, and raised up to $80 \%$ after $24 \mathrm{hr}$ exposure time (Fig. $2 \mathrm{~A}$ and B).

Similarly, E. aerogenes exhibited the same killing pattern towards HeLa cells when they harboured pks cluster genes (Fig.2 C and D). When normal cells were treated with $p k s-$ Enterobacter for $6 \mathrm{hr}$, they conferred viability of around $90 \%$, however, they cannot get longer when they were exposed for $24 \mathrm{hr}$ with pks+E. aerogenes isolates (killing activity around $75 \%$ ). 


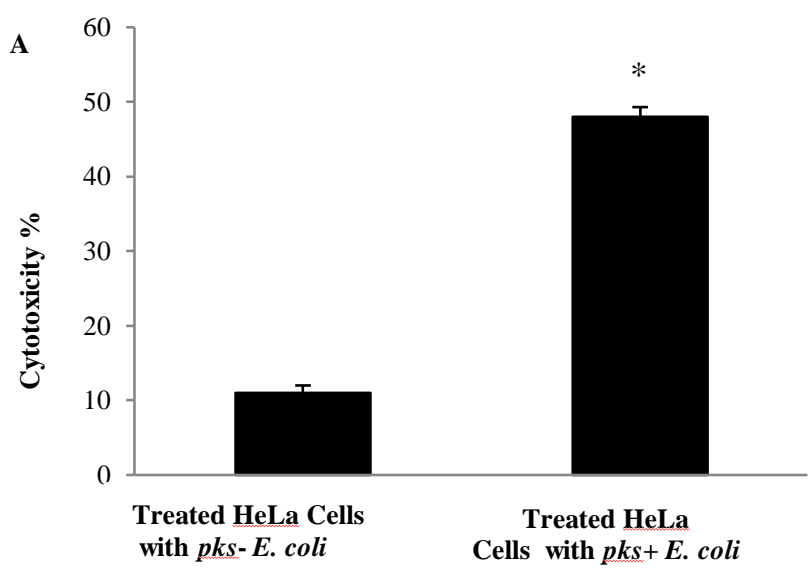

Incubation time/6 hr

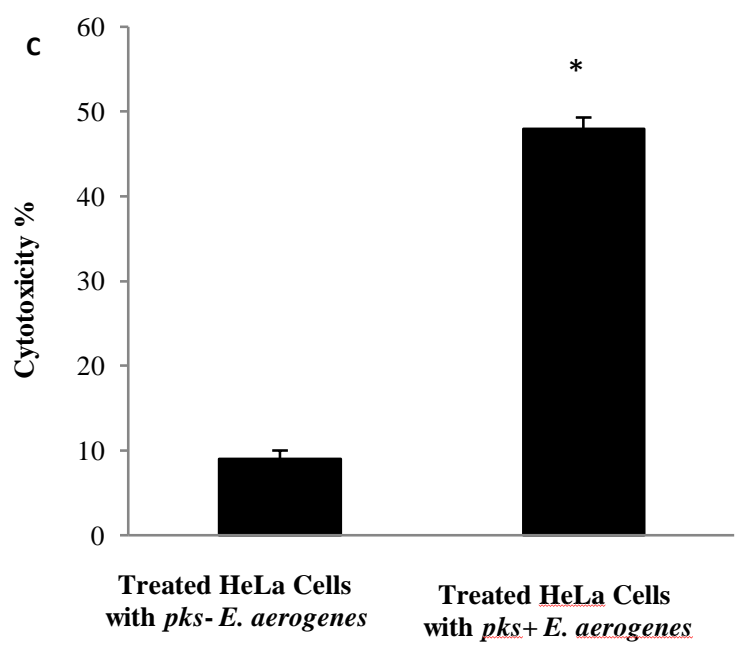

Incubation time/6 hr

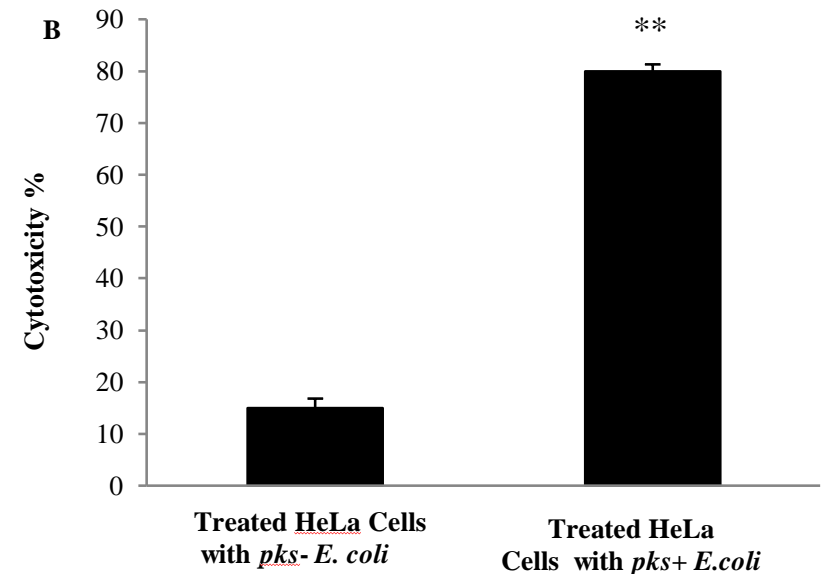

Incubation time $/ 24 \mathrm{hr}$

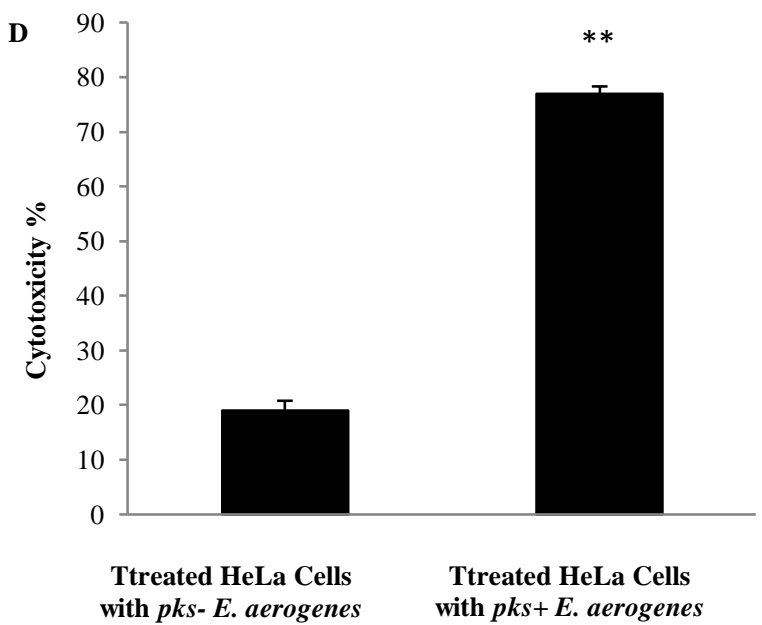

Incubation time $/ 24 \mathrm{hr}$

Figure 2. Cytotoxic activity of clb in Enterobactereacea.

Normal Hela cell cultures were exposed to 2 isolates of Enterobactereacea at MOI 50 for 6 and $24 \mathrm{hr}$ under optimal conditions. A: HeLa cells with $p k s-E$. coli; B: Hela cells with $p k s+$ E. coli; $\mathrm{C}$ : HeLa cells with $p k s-E$. aerogenes; and D: HeLa cells with $p k s+$ Enterobacter. Data expressed as mean \pm SD. $* P<0.05$, ** $P<0.01$.

\section{Induced megalocytosis in response to $E$. coli and} E. aerogenes infections

In the current study, the efficiency and cytotoxicity of $p k s+$ bacterial isolates encoding $c l b$ genes were examined on HeLa cell cultures at MOI 50. The cells were treated with both $E$. coli and $E$. aerogenes harbouring $\mathrm{clb}$ genes for 6 and $24 \mathrm{hr}$. From the microscopic observation of the cellular morphological phenotypes, In this study, the treated HeLa cells revealed some responses to the colibactin; the cytopathic phenotype of this genotoxin was represented by decreasing cell numbers and enlargement of cell nucleus, which could be due to DNA fragmentation and cell cycle arrest, in comparison to the untreated cells (control) (Fig. $3 \mathrm{~A}$ and $\mathrm{B})$. 

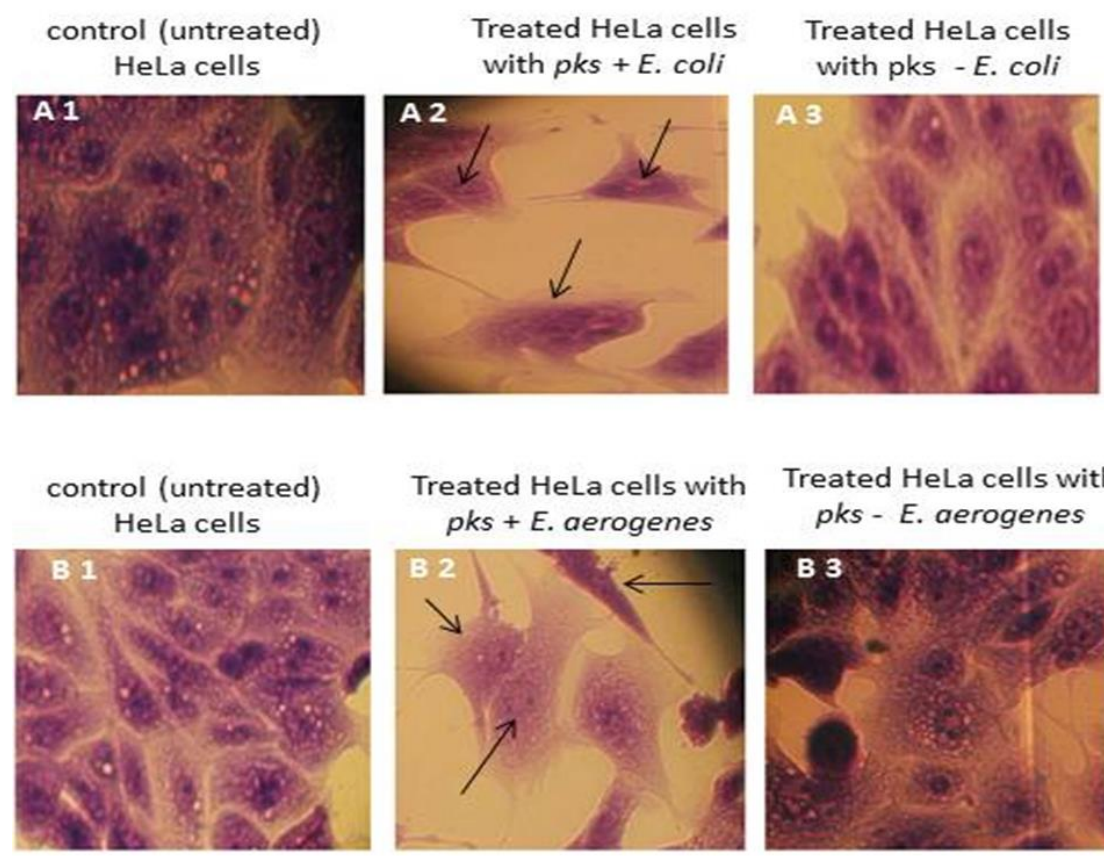
Treated HeLa cells with pks - E. aerogenes

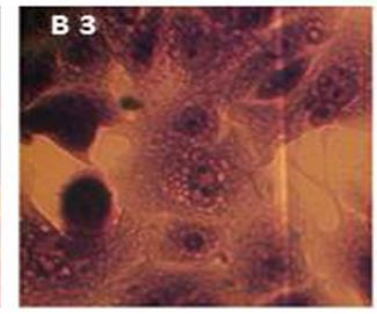

Figure 3. Cell culture assay for cytotoxicity.

(A1, B1) HeLa cells were untreated (negative control), (A2, B2) HeLa cells treated with pks+E. coli and E. aerogenes (A3, B3) HeLa cells treated with $p k s-E$. coli and E. aerogenes at MOI of 50 for $6 \mathrm{hr}$ incubation in Gentamicin-containing medium. The black arrows in (A2, B2) indicated the morphological changes in treated HeLa cells with pks+ isolates such as enlargement and multinucleation (displayed megalocytosis). Images were taken at $40 \mathrm{x}$ magnification using Inverted microscopic.

The results of fluorescence microscopy of HeLa cells treated with bacterial isolates ( $p k s+$ and $p k s-$ ) with $\mathrm{AO} / \mathrm{EB}$ staining showed different staining patterns of the nuclei. After the treatment of HeLa cells with $p k s-$ bacterial isolate $E$. coli and $E$. aerogenes (living cells) (Fig. 4 A and D), the nuclear chromatin appeared in different forms of condensation and degradation; the nuclei were greenyellow, yellow-orange to yellow in color. While, in the dead HeLa cells treated with pks+E. coli and $E$. aerogenes, the nuclei appeared orange, dark and bright red in color. Following the treatment of control (living cells), the nuclei appeared in green color and without any condensation, degradation or fragmentation (Fig. $4 \mathrm{C}$ and $\mathrm{F}$ untreated cells). Taking the above results together, this indicate that the colibactin-producing $E$. coli and $E$. aerogenes were able to decrease the number of infected mammalian cells and generate morphological changes.
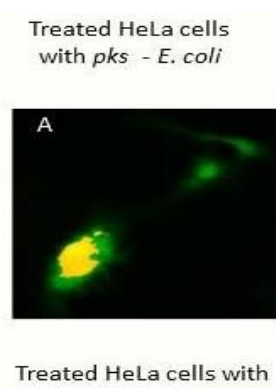
pks - E. aerogenes

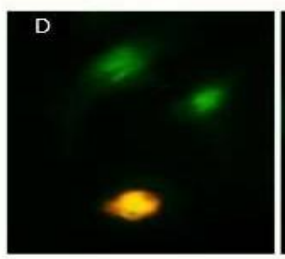

Treated Hela cells with $p k s+E$. aerogenes

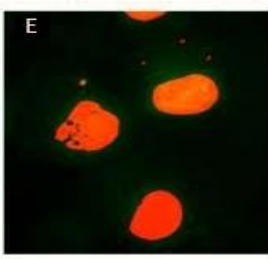

control (untreated)

HeLa cells
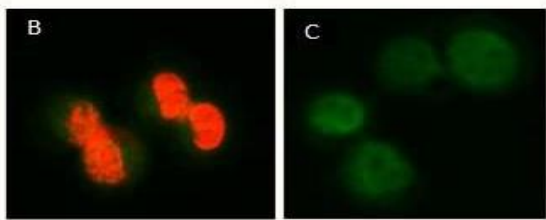

control (untreated) HeLa cells

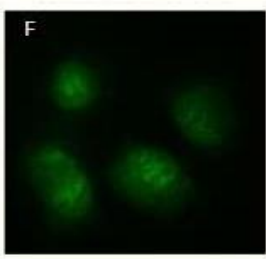

Figure 4. Fluorescent micrographs of AO/EBr-double-stained. 
(A) HeLa cells treated with $p k s-E$. coli, (B) HeLa cells treated with pks+E. coli, (C) Control (untreated) HeLa cells, (D) HeLa cells treated with $p k s-$ E. aerogenes, (E) HeLa cells treated with $p k s+$ E. aerogenes, (F) Control (untreated) HeLa cells, at MOI 50 as indicated. All treated cells were incubated for $24 \mathrm{hr}$ at $37^{\circ} \mathrm{C}$. Scale bar $10 \mu \mathrm{m}$.

\section{Discussion:}

The pks gene cluster encodes a number of multi domain enzymes that are responsible for the synthesis of the genotoxin colibactin that typically synthesize secondary metabolites in several types of microbial species. This genotoxin was shown to play an important role in the induction of the damage and breaks in the DNA of host cells. Colibactin may contribute in causing different disease entities, in addition to cell damages and increased virulence in bacteria. A member of the family Enterobacteriaceae is found widely in the gastrointestinal tract of many mammals, including almost all humans. The presence of $p k s$ gene in some of pathogenic and nonpathogenic $E$. coli has been implicated in the induction of the formation of colorectal tumors in animals like mice. Some studies reported that the $p k s$ gene was more highly represented in the intestinal mucosa in CRC patients than in non-CRC controls. The presences of $p k s$ genes vary according to clinical samples; these genes were found in $20 \%$ of the stool samples investigated by (22) and found in $32 \%$ of $E$. coli strains isolated from feces of hospitalized veterans (5). In this study, a total of 88 clinical isolates were obtained from stool, urine and blood, which then be diagnosed as an E. coli, K. pnuemonia and $E$. aerogenes. The prevalence of $p k s$ genes was found in all these isolates. The distribution of colibactin-producing genes is not restricted to such strains; K. pnuemoniae strain 1084 was shown to promote severe damage to the DNA of liver parancymal cells in BALB/c mice, and the molecular detection revealed that it harbors clbA gene, compared to $c l b A$ deletion mutant strain which was unable to persist the infection. In addition, the predominance of $p k s$ genes in $K$. pnuemoniae strain1084 is around $25.6 \%$ in Taiwan (3). Moreover, K1 CC23 K. pneumoniae is considered as a hyper virulence strain, due to the presence of $p k s$ genes, particularly $c l b A$, which participated in the development of meningitis in BALB/c mice, in comparison to the mutant strain where the production of colibactine is attenuated [8]. In Iran, it was found that the occurrence of $c l b$ genes is varied, with 23.23 $\%$ is for $c l b B$ and $20 \%$ for $c l b N$ and $13.33 \%$ for both genes in 30 samples of $K$. pneumoniae isolated from CRC patients (24). Interestingly, it was found that $c l b B+E$. coli isolated from colonic mucosa of patients with familial adenomatous polyposis (FAP) is able to increase the level of IL-17 in colon and induce DNA damage in colonic epithelium. This suggests the relatedness of colibactin-producing genes to increase and induce tumor in the host cell (25). The indispensable role of $c l b B$ and $c l b N$ in colibactin synthesis is at the early step of producing pre-drug (N-acyl-D-Asparagine), which then undergoes protease activity to produce a mature colibactin (15). It was stated that both cob and clone are related to bacteremia, with prevalence percentage of $58 \%$ from blood samples and $23 \%$ from feces (5). This is not consistence with our findings of the occurrence of $\mathrm{clb} \mathrm{B}$ and clone not only in blood samples, but also in urine and stool specimens. Our results are in agreement with (24), where both genes were isolated from $E$. coli, $K$. pneumoniae, $E$. aerogenes and $C$. koseri. All of the pks+ bacterial isolates were significantly more susceptible to 10 of the 14 antibiotics tested (Table 5). The present results showed that amongst antibiotics, imipenem was the strongest antibiotic inhibitor for the growth of all pks+ bacterial isolates, also including fluoroquinolons, $\beta$-lactam and glycosides. It has been also observed that theses isolates show susceptibility to nitrofurantion with a percentage of inhibitory effects of $94 \%$. On the other side, ciprofloxacin was the only antibiotic to which there was no significant difference in rates of susceptibility between the pks+ and $p k s$ - isolates. There are several studies which reported that the bacterial isolates particularly $K$. pneumoniae harbouring the pks colibactin gene cluster are considered as highly associated with low levels of antimicrobial resistance, since most of the isolated bacteria belong to $\mathrm{K} 1$ and $\mathrm{K} 2$ capsular types, as isolates of these capsular types recovered from KLA cases are usually less resistance to other antimicrobial agent. On the other hand, $(26,27)$ reported that the emergence of multidrug resistance, combined with genotoxicity in hypervirulent $K$. pneumoniae strains, is worrisome and that there might be more strains of Enterobacterial that will be discovered with the resistance of antibiotics phenotypes. Careful monitoring of isolates with genotoxic colibactin pks gene cluster for acquired antimicrobial resistance is warranted $(28,29)$. To mimic the genotoxic efficiency of colibactineproducing isolates in vitro, HeLa cell was used. The histological changes of infected HeLa cells were associated with reduction in the number of cells, and enlargement of cells size, compared to the normal cells. In addition, the cytotoxic level of $p k s+$ isolates was determined and observed. The ability of pks+ harboring strains to induce DNA damage was 
reported in the studies of (30-33). The HeLa cell culture was exposed to colibactine-producing $E$. coli for 4 hours and stained with a marker for DNA damage. The DNA inter-strand cross link was clearly obvious, and thus those data are in agreement with our results. The cytotoxicity of genotoxin (colibactin) requires live bacteria and direct attachment between the bacteria harbouring $\mathrm{clb}$ genes and mammalian cells $(1,34)$. This part supports the hypothesis that the bacteria which have the ability to produce the genotoxin colibactin can play an important role in inducing tumorigensis and development of colorectal cancer.

\section{Conclusion:}

In the present study, the occurrence and prevalence of colibactin-encoding genes among various clinical bacterial specimens, including those from stool, urine, and blood was confirmed using a PCR technique. The presence of pks-polyketide clusters in the isolated bacteria spots the light on how these microbes could cause damage to the host cell. One of the most efficient ways to disrupt host cell is by triggering endotoxins, exotoxins and genotoxins. Overall, this pilot study indicates that the pks+ Enterobacteriaceae isolates have the ability to produce genotoxin which may induce damage in the DNA and make a histological transformation. Colibactin is polyketide molecules that is released from pathogenic and non-pathogenic bacteria, and from bacteria related to CRC in particular. There are four genes detected to be involved in the production of colibactin; $c l b A, c l b B, c l b N$ and $c l b Q$ and to play an important role in the biosynthesis of genotoxin. Moreover, our finding indicate that the ability of $p k s+$ members of the family Enterobacteriaceae to persist and colonize the human gut and infect the organs, and their cytotoxicity towards mammalian cells.

\section{Authors' declaration:}

- Conflicts of Interest: None.

- We hereby confirm that all the Figures and Tables in the manuscript are mine ours. Besides, the Figures and images, which are not mine ours, have been given the permission for re-publication attached with the manuscript.

- The author has signed an animal welfare statement.

- Ethical Clearance: The project was approved by the local ethical committee in University of Baghdad.

\section{References:}

1. Nougayrède J-P, Homburg S, Taieb F, Boury M, Brzuszkiewicz E, Gottschalk, G, et al. Escherichia coli induces DNA double-strand breaks in eukaryotic cells. Science. 2006 Aug; 313:848-851.

2. Cuevas-Ramos G, Petit CR, Marcq I, Boury E, Oswald M, Nougayrede JP. Escherichia coli induces DNA damage in vivo and triggers genomic instability in mammalian cells. Proc. Natl. Acad. Sci. 2010 Jun; 107: 11537-11542.

3. Bondarev V, Richter M, Romano S, Piel J, Schwedt A, Schulz-Vogt HN. The genus Pseudovibrio contains metabolically versatile bacteria adapted for symbiosis. Environ. Microbiol. 2013 Jul; 15:2095-2113.

4. Cougnoux A, Delmas J, Gibold L, Faïs T, Romagnoli C, Cuevas-Ramos G, et al. Small-molecule inhibitors prevent the genotoxic and protumoural effects induced by colibactin-producing bacteria. Gut 2016 Feb; 65: 278-285.

5. Bian X, Plaza A, Zhang Y, Muller R. Two more pieces of the colibactin genotoxin puzzle from Escherichia coli show incorporation of an unusual 1aminocyclopropanecarboxylic acid moiety. Chem. Sci. 2015 May; 6: 3154-3160.

6. Brotherton CA, Wilson M, Byrd G, Balskus EP. Isolation of a metabolite from the $p k s$ island provides insights into colibactin biosynthesis and activity. Org. Lett. 2016 Mar; 17: 1545- 1548.

7. McCarthy AJ, Martin P, Cloup E, Stabler RA, Oswald E, Taylor PW. The genotoxin colibactin is a determinant of virulence in Escherichia coli $\mathrm{K} 1$ experimental neonatal systemic infection. Infect. Immun. 2015 Sep; 83: 3704-3711.

8. Brotherton CA, Balskus EP. A prodrug resistance mechanism is involved in colibactin biosynthesis and cytotoxicity. J. Am. Chem. Soc. 2013 Mar; 135: 33593362.

9. Johnson JR, Johnston B, Kuskowski MA, Nougayrede JP, Oswald E. Molecular, epidemiology and phylogenetic distribution of the Escherichia coli pks genomic island. J. Clin. Microbiol. 2008 Dec; 46: 3906-3911.

10. Cohen J. The immunopathogenesis of sepsis. Nature. 2002 Dec; 420: 885-891.

11. Bossuet-Greif N, Vignard J, Taieb F, Mirey G, Dubois $\mathrm{D}$, Petit $\mathrm{C}$, et al. The colibactin genotoxin generates DNA inter-strand crosslinks in infected cells. mBio. 2018 Mar; 9: e02393-17.

12. Lu MC, Chen YT, Chiang MK, Wang YC, Hsiao PY, Huang YJ, et al. Colibactin contributes to the hypervirulence of $p k s(+) \quad \mathrm{K} 1 \quad \mathrm{CC} 23 \quad$ Klebsiella pneumoniae in mouse meningitis infections. Front. Cell. Infect. Microbiol. 2017 Mar;7: 103.

13. Putze J, Hennequin C, Nougayrede JP, Zhang W, Homburg S, Karch $\mathrm{H}$. et al. Genetic structure and distribution of the colibactin genomic island among members of the family Enterobacteriaceae. Infect. Immun. 2009 Dec; 77: 4696-4703.

14. Hancock V, Seshasayee AS, Ussery DW, Luscombe NM, Klemm P. Transcriptomics and adaptive 
genomics of the asymptomatic bacteriuria Escherichia coli strain 83972. Mol. Genet. Genom. 2008 May; 279: 523-534.

15. Marcq I, Martin P, Payros D, Cuevas-Ramos G, Boury M, Watrin C, et al. The genotoxin colibactin exacerbates lymphopenia and decreases survival rate in mice infected with septicemic Escherichia coli. J. Infect. Dis. 2014 Jul ; 210: 285-294.

16. Raisch J, Buc E, Bonnet M, Sauvanet P, Vazeille E, de Vallee. et al. Colon cancer-associated B2 Escherichia coli colonize gut mucosa and promote cell proliferation. World J. Gastroenterol. 2014 Jun; 20: 6560-6572.

17. Faïs T, Cougnoux A, Dalmasso G, Laurent F, Delmas J, Bonnet R. Antibiotic activity of Escherichia coli against multiresistant Staphylococcus aureus. Antimicrob. Agents Chemother. 2016 Nov; 16: 69866988.

18. CLSI. In: Performance standards for antimicrobial susceptibility testing. 29th ed. Wayne, PA: Clinical and Laboratory Standards Institute. 2019; CLSI supplement M100.

19. Freshney RI. Culture of Animal Cells. A Manual of Basic Technique and Specialized Applications, Sixth Ed. Hoboken, NJ: 2010; John Wiley \& Sons, Inc.

20. Bossuet-Greif N, Belloy M, Boury M, Oswald E, Nougayrede J. Protocol for HeLa cells infection with Escherichia coli strains producing colibactin and quantification of the induced DNA-damage. Bioprotocol. 2017Aug; 7(16): e2520.

21. SAS. (2012) Statistical Analysis System, User's Guide. Statistical. Version 9.1th ed. SAS. Inst. Inc. Cary. N.C. USA.

22. Arthur JC, Perez-Chanona E, Mühlbauer M, Tomkovich S, Uronis JM, Fan TJ, et al. Intestinal inflammation targets cancer-inducing activity of the microbiota. Science. 2012 Nov ; 338: 120-123.

23. Lai Y-C, Lin A-C, Chiang M-K, Dai Y-H, Hsu C-C, Lu M-C, et al. Genotoxic Klebsiella pneumoniae in Taiwan. PLoS ONE. 2014 May; 9: e96292.

24. Cheraghi A, Ganji SM, Najmi B. Analysis of $c l b N$ and $c l b B$ genes in Isolated Klebsiella pneumonia of biopsies from patients with colorectal cancer. IJML. 2016 Nov; 3: 163-169.

25. Dejea CM, Fathi P, Craig JM, Boleij A, Taddese R, Geis AL. et al. Patients with familial adenomatous polyposis harbor colonic biofilms containing tumorigenic bacteria. Science. 2018 Feb; 359: 592597.

26. Luo Y, Wang Y, Ye L, Yang J. Molecular epidemiology and virulence factors of pyogenic liver abscess causing Klebsiella pneumoniae in China. Clin. Microbiol. Infect. 2014 Nov; 20: O818-O824.

27. Fang CT, Lai SY, Yi WC, Hsueh PR, Liu KL, Chang SC. Klebsiella pneumoniae genotype K1: an emerging pathogen that causes septic ocular or central nervous system complications from pyogenic liver abscess. Clin. Infect. Dis. 2014 Aug; 45: 284-293.

28. Chen Y-T, Lai YC, Tan MC, Hsieh LY, Wang JT, Shiau YR. Prevalence and characteristics of $p k s$ genotoxin gene cluster-positive clinical Klebsiella pneumoniae isolates in Taiwan. Sci. Rep. 2017 Feb; 7: 43120.

29. Mustafa MS, Abdullah RM. Detection of $16 \mathrm{~S}$ rRNA Methylases and Co-Resistance with $\beta$-lactams among Klebsiella pneumoniae isolates from Iraqi Patients. Baghdad Sci. J. 2019 Sep; 16: 580-587.

30. Nowrouzian FL, Oswald E. Escherichia coli strains with the capacity for long-term persistence in the bowel microbiota carry the potentially genotoxic pks island. Microb. Pathog. 2012 Sep; 53: 180-182.

31. Balbo S, Hecht SS, Upadhyaya P, Villalta PW. Application of a high-resolution mass-spectrometrybased DNA adductomics approach for identification of DNA adducts in complex mixtures. Anal. Chem. 2014 Feb; 86: 1744-1752.

32. Marcq I, Martin P, Payros D, Cuevas-Ramos G, Boury M, Watrin $\mathrm{C}$, et al. The genotoxin colibactin exacerbates lymphopenia and decreases survival rate in mice infected with septicemic Escherichia coli. J. Infect. Dis. 2014 Jul; 210: 285-294.

33. Shine EE, Xue M, Patel JR, Healy AR, Surovtseva YV, Herzon SB, et al. Model colibactins exhibit human cell genotoxicity in the absence of host bacteria. ACS Chem. Biol. 2018 Sep; 13: 3286-3293.

34. Morgan RN, Saleh SE, Farrag HA, Aboulwafa MM. Prevalence and pathologic effects of colibactin and cytotoxic necrotizing factor-1 (Cnf 1) in Escherichia coli: experimental and bioinformatics analyses. Gut Pathol. 2019 May; 19: 11-22. 


\section{انتثار و تثخيص بعض جينات الكولبكتين في العزلات الممرضة في العائلة المعوية المعزولة من مرضى عراقيين}
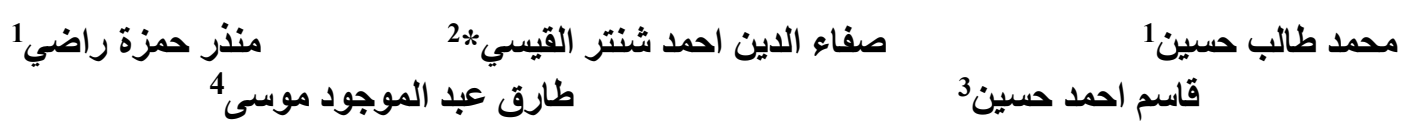

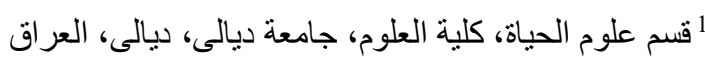

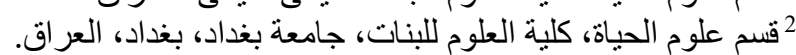

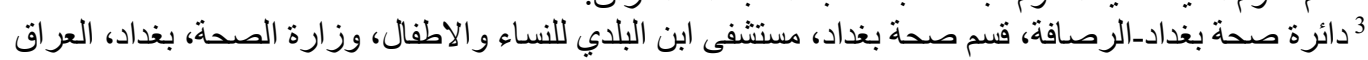

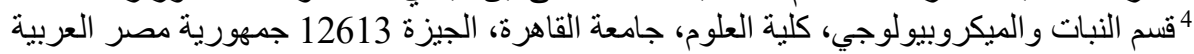

افر اد العائلة المعوية تمتلك مجموعة من الجينات تدعى (Polyketide synthase (pks). هذه المجموعة من الجينات تكون مسؤولة

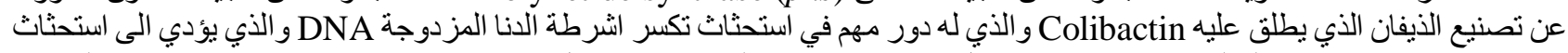

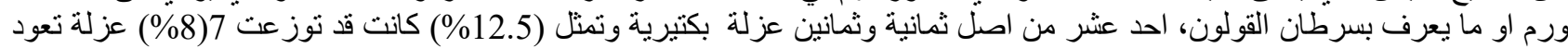
E. aerogenes كانت حاملة لجينات الكولبكتين

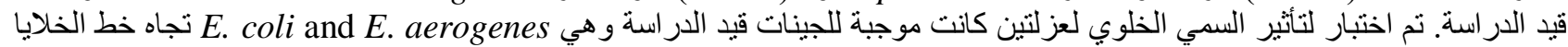

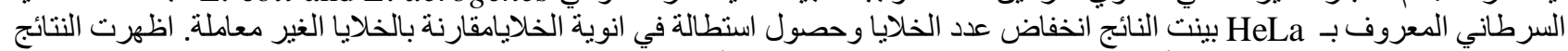

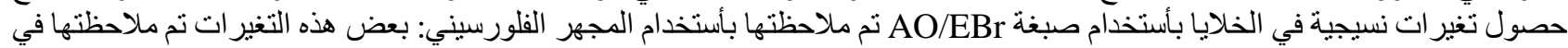

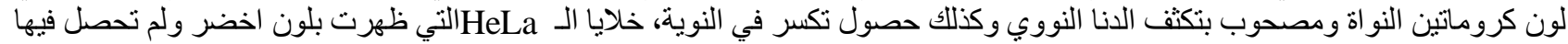

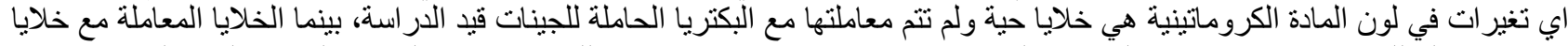

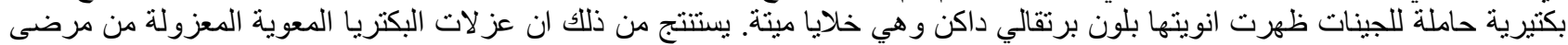

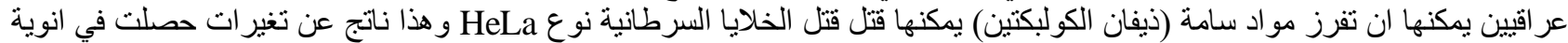

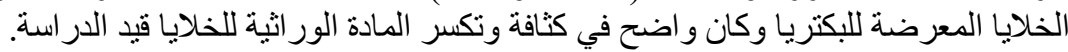

الكلمات المفتاحية: الكولبكتين، السمية الخلوية، العائلة المعوية، الذيفانات الجينية، انتشار 